\title{
Induction of Drug Metabolizing Enzymes by Polychlorinated Biphenyl in the Parotid Gland and Relation to Changes in Vitamin A Content and Morphological Changes
}

\author{
Goro Kawasaki ${ }^{1}$, Shiro Mataki ${ }^{2}$ and Kunio Takano ${ }^{3}$ \\ ${ }^{I}$ First Department of Oral and Maxillafacial Surgery, ${ }^{2}$ Department of Pharmacology and ${ }^{3}$ Second Department of Oral Anatomy, \\ Nagasaki University School of Dentistry, 1-7-1, Sakamoto, Nagasaki 852, Japan \\ Received June 1, 1994 Accepted August 15, 1994
}

\begin{abstract}
The relationship between the morphological changes and vitamin A content during the development of acute toxicity induced by polychlorinated biphenyl (PCB) in mouse parotid glands was investigated. PCB was administered intraperitoneally at a single dose of $2 \mathrm{mg} / \mathrm{kg}$. Ultrastructural studies revealed remarkable morphological changes in the rough endoplasmic reticulum, nucleus, Golgi apparatus and the secretory granules at 7 days after the administration of PCB. The activities of adenosine monophosphatase (AMPase) and alkaline phosphatase were increased 1 day after PCB administration. Then the activity of NADPH-cytochrome $c$ reductase increased 4 days after PCB administration. Subsequently, the vitamin A content of the parotid glands significantly decreased at 7 days compared with the control. These sequential changes in enzyme activities implied that the decrease of vitamin A content in the parotid glands may be partly due to catabolism of vitamin A by increased activities of microsomal enzymes induced by $\mathrm{PCB}$. In conclusion, it is suggested that $\mathrm{PCB}$ also induces drug metabolizing enzymes in the parotid gland cells and that the acute toxicity of PCB on this tissue may occur, at least partly, through the reduction of vitamin A not only by the secondary effect from liver impairment but also by the locally accelerated catabolism of vitamin A in the mouse parotid gland.
\end{abstract}

Keywords: Polychlorinated biphenyl, Vitamin A, NADPH-cytochrome c reductase, Parotid gland

Polychlorinated biphenyl (PCB) is well known as one of the widespread environmental contaminants. Since PCBs are lipophilic and the metabolism of these molecules is slow in vivo, they accumulate in the body and induce adverse effects on health $(1,2)$.

In Japan, over 1000 people used rice oil contaminated with PCB and subsequently they have been suffering from nausea, lethargy, subcutaneous edema of the face and acne-like skin lesions. These symptoms are called Yusho in Japan.

Although the toxicity of PCB in humans and animals has been reported (3), its mechanism is still poory understood. In past years, the close relationship between PCB toxicity and vitamin $A$ has been demonstrated. For example, studies in rabbits showed that the concentration of liver vitamin A was lower in animals receiving PCB (Aroclor 1254) than in control animals (4). The activity of microsomal cytochrome P-450 systems has been shown to increase after the administration of $\operatorname{PCB}(5,6)$, and it has been suggested that a microsomal enzyme system may play an important role in the mechanism of vitamin $A$ reduction in animals treated with $\mathrm{PCB}(7)$.

Since dysgeusia and xerostomia were reported in Yusho patients, these symptoms may be closely related to a disease of the salivary gland. In this context, an ultrastructural study on the changes of von Ebner's gland in the rat following PCB administration was reported (8); however, the effect of PCB on the major salivary gland has not yet been addressed. On the other hand, other investigators reported that vitamin A deficiency affects the salivary gland (9).

The purpose of the present experiment was to examine the relationship among the histopathological changes, changes in vitamin A content and microsomal enzyme activity in mouse parotid gland after PCB injection.

\section{MATERIALS AND METHODS}

Four-week-old male ddy mice were given a single intraperitoneal injection of PCB ( $2 \mathrm{mg} / \mathrm{kg}$ body weight) dis- 
solved in corn oil. PCB (Kanechlor KC-400), which is mainly composed of tetrachlorobiphenyl, was purchased from GL Science Co., Ltd. The control mice were each injected with the equivalent volume $(0.5 \mathrm{ml} / \mathrm{kg}$ body weight) of corn oil. Mice were housed in cages maintained in a laboratory with $12 \mathrm{hr}$ of light and $12 \mathrm{hr}$ of darkness. The temperature in the laboratory was controlled at $22^{\circ} \mathrm{C}$. Food and water were given ad libitum throughout the experiments. Mice were sacrificed 1 day, 4 days, 7 days, 2 weeks, 4 weeks, 8 weeks and 16 weeks after PCB administration; and both of the parotid glands of each animal were dissected out. Each group consists of 7 mice.

For the electron microscopic studies, mice were fixed by vascular perfusion of fixative at room temperature through the ascending aorta of anesthetized animals. After 10-15 min of perfusion, the parotid glands were removed and placed in fresh fixative at $4{ }^{\circ} \mathrm{C}$. The total fixation time was 2 to $6 \mathrm{hr}$ for the morphological studies. The fixative was $2 \%$ glutaraldehyde and $2 \%$ paraformaldehyde in $0.1 \mathrm{M}$ phosphate buffer ( $\mathrm{pH}$ 7.4). After fixation, the tissue was placed in $0.1 \mathrm{M}$ phosphate buffer with $10 \%$ sucrose, $\mathrm{pH} 7.4$, trimmed into small pieces and stored overnight at $4{ }^{\circ} \mathrm{C}$. Postfixation was done with $1 \%$ osmium tetroxide in $0.1 \mathrm{M}$ phosphate buffer, $\mathrm{pH}$ 7.4. Following postfixation, the tissue was dehydrated in ethanol and embedded in Epon 812. These sections were stained with uranyl acetate and lead citrate, and they were examined with an $\mathrm{H}-800$ electron microscope operated at $75 \mathrm{kV}$.

For the biochemical analyses, mice were sacrificed by cervical dislocation. Then the parotid glands were immediately dissected out, and thereafter they were homogenized and used for the determinations of vitamin A content and activities of NADPH-cytochrome $\mathrm{c}$ reductase, AMPase and alkaline phosphatase.

Vitamin $\mathrm{A}$ in the parotid gland was assayed by the method of Katui (10). Briefly, the reaction mixture containing water and ethanol was added to the homogenized solution. Then the mixture was shaken vigorously with $n$ hexane at room temperature for $5 \mathrm{~min}$ and centrifuged at $1000 \mathrm{rpm}$ for $5 \mathrm{~min}$. The supernatant solution was distilled in a water bath at $30^{\circ} \mathrm{C}$, and $100 \mu \mathrm{l}$ of isopropanol was added to it. A 20- $\mu 1$ aliquot of each sample was injected onto a $\mathrm{C} 18$ reverse phase column and vitamin A was detected by spectrofluorometer.

The NADPH-cytochrome $c$ reductase activity of the parotid gland was assayed by measuring the rate of reduction of cytochrome $\mathrm{c}$ by NADPH (11). The reaction mixture contained $20 \mu \mathrm{M}$ cytochrome c, $10 \mathrm{mM}$ NADPH, 1 $\mathrm{mM} \mathrm{KCN}$ and enzyme solution in $2 \mathrm{ml}$ of $0.1 \mathrm{M}$ potassium phosphate buffer ( $\mathrm{pH} 7.5)$. The reaction was started by the addition of NADPH, and the increase in optical density at $550 \mathrm{~nm}$ was measured at $25^{\circ} \mathrm{C}$.

Alkaline phosphatase was assayed with $1 \mathrm{mg} / \mathrm{ml}$ $p$-nitrophenyl phosphate as substrate in $0.3 \mathrm{mM} \mathrm{MgCl}$, $50 \mathrm{mM}$ sodium barbital buffer, $\mathrm{pH} 10.5$ (12). Fifty microliters of each sample diluted in Triton X-100 were assayed. Samples were incubated for $80 \mathrm{~min}$ at $37^{\circ} \mathrm{C}$ in the assay mixture, and the reaction was terminated by the addition of $100 \mu 11 \mathrm{~N} \mathrm{NaOH}$. The absorbance at $410 \mathrm{~nm}$ was read immediately.

AMPase was assayed at $\mathrm{pH} 7.5$ with $0.005 \mathrm{M}$ AMP as a substrate in the presence of $0.01 \mathrm{M} \mathrm{MgCl}_{2}$, according to the method of Song and Bodansky (13). Protein was determined as described by Lowry et al. (14).

\section{RESULTS}

The electron microscopic appearance of parotid acinar cells from control mice was essentially identical to that described for other serous exocrine glands (Fig. 1). The nucleus and parallel arrays of endoplasmic reticulum filled the basal portion of the cytoplasm, while the apical region was filled with homogenous electron-dense secretory granules. An extensive Golgi apparatus, with condensing vacuoles of varyng size and density, was located apical or lateral to the nucleus. The endoplasmic reticulum took the form of flattened membranous vesicles that are commonly known as cisternae. Lysosomes were found in most of the acinar cells.

There were no differences in the parotid acinar cells from mice at 1 day and 4 days after PCB administration compared with the control, although the lysosomes increased at 4 days (Fig. 2). At 7 days after PCB administration, the parotid gland acinar cells showed several histopathological changes.

The nucleus showed pycnosis (Fig. 3). Most Golgi profiles were reduced in size. There were many altered secretory granules with an electron dense substance in their peripherals, while the central portion of the granules was less-electron dense and occasionally contained a few clusters of dense material (Fig. 4). On the other hand, several fused secretory granules were also observed (Fig. 5).

In addition, large vacuoles could be seen in the cytoplasm of many acinar cells, and some of vacuoles contained a myelin-like body within themselves (Fig. 6).

Remarkable morphological changes were observed in the rough endoplasmic reticulum. In normal cells, the innerspace of the lumen of the rough endoplasmic reticulum had a constant width that was relatively narrow. However, in PCB-injected mice, the width of the rough endoplasmic reticulum was quite variable from one site to another, and its appearance was irregular and discontinuous (Fig. 7). At 2 weeks after PCB administration and thereafter, no morphological changes were found compared with controls (Fig. 8). 
a

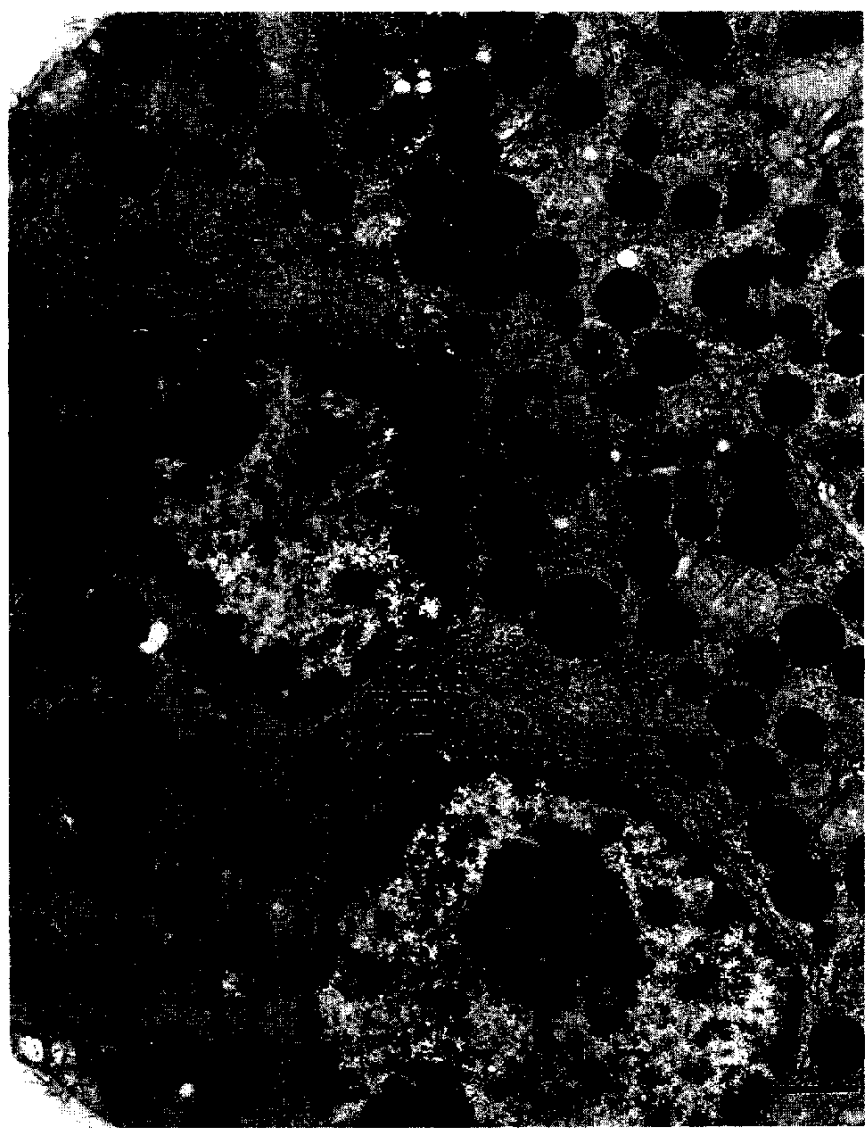

b

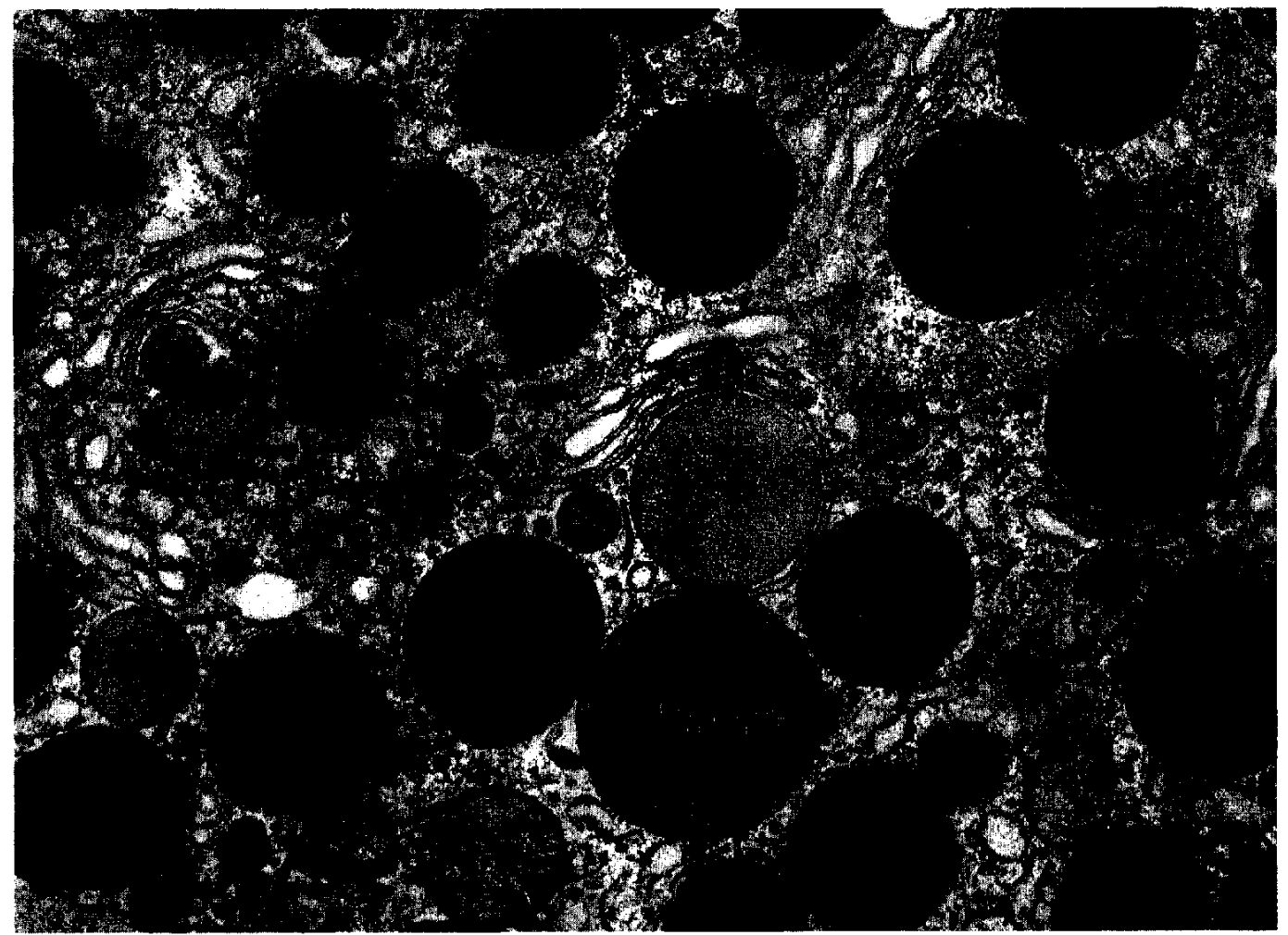

Fig. 1. Electron micrograph of a control mouse parotid gland acinar cell. a: N, nucleus; SG, secretory granule; RER, rough endoplasmic reticulum. $\times 3500, \mathrm{Bar}=1 \mu \mathrm{m}$. b: Homogenous secretory granules (SG) can be seen. G, Golgi. $\times 10000$, Bar $=1 \mu \mathrm{m}$. 


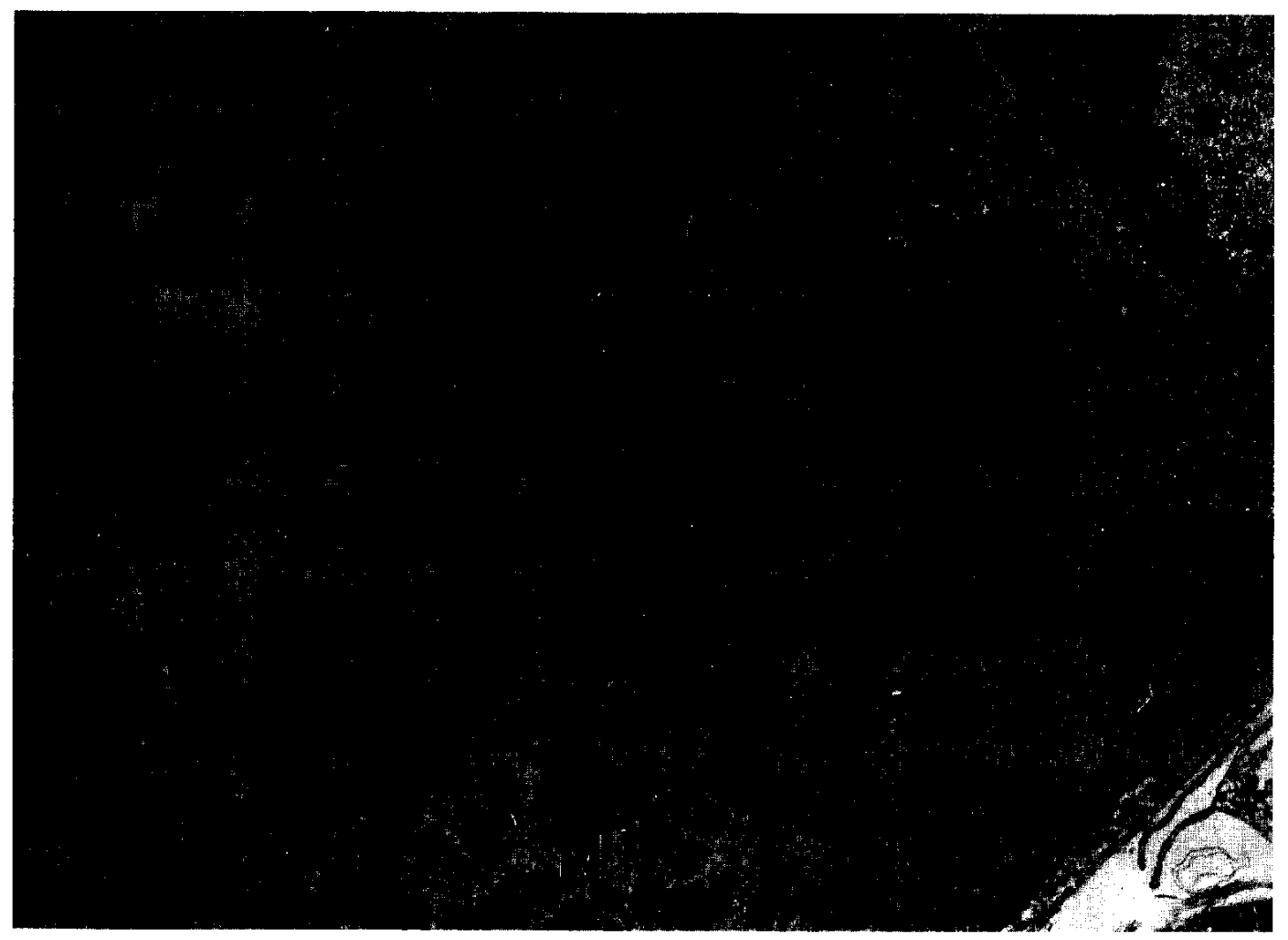

Fig. 2. Electronmicrograph of a parotid gland acinar cell at 4 days after PCB. Increased lysosome can be seen. Ly, lysosome; $\mathrm{N}$, nucleus. $\times 2500, \mathrm{Bar}=1 / \mathrm{m}$.

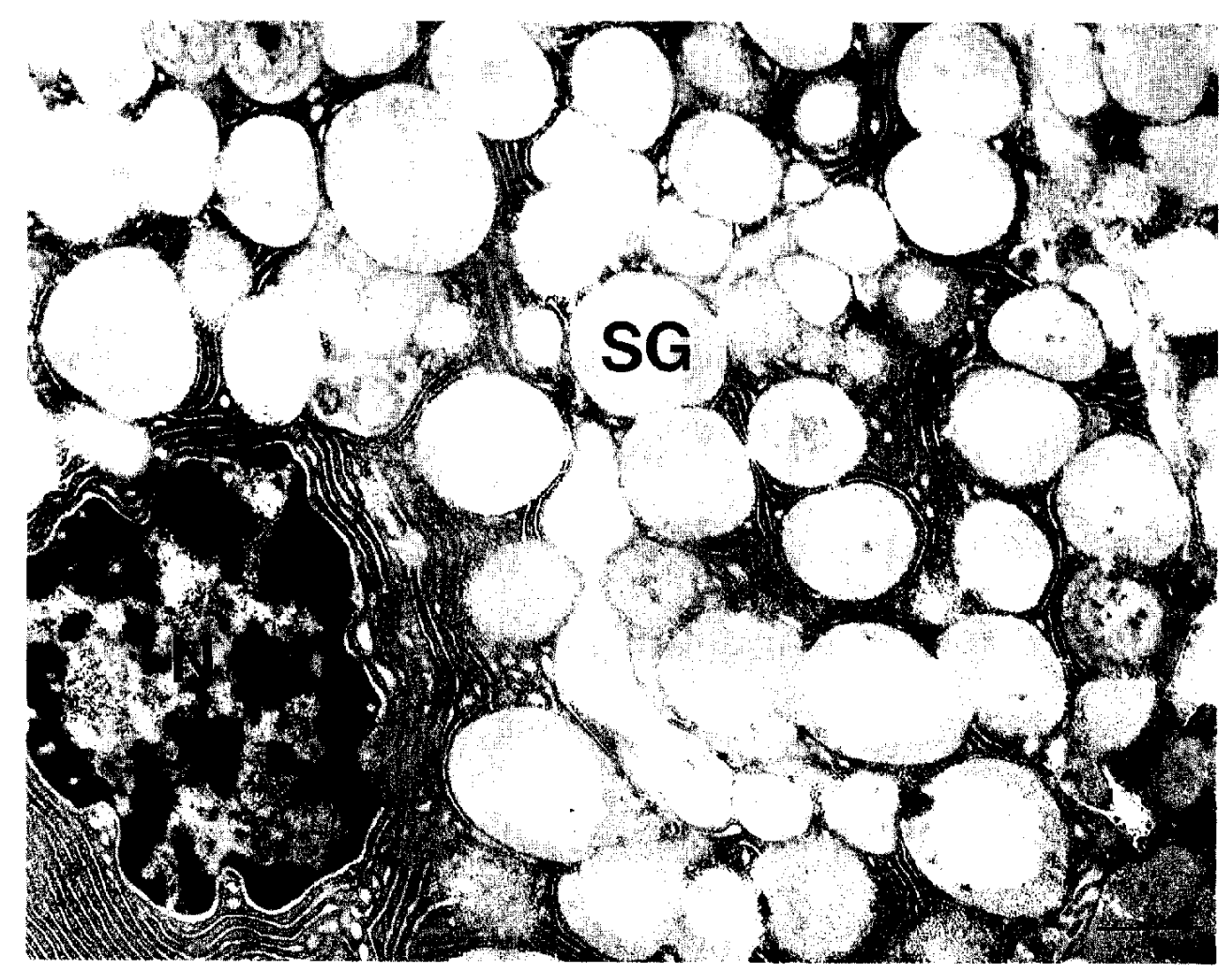

Fig. 3. Electronmicrograph of a parotid gland acinar cell at 7 days after PCB. The nucleus (N) shows pycnosis. SG, secretory granule. $\times 5000, \mathrm{Bar}=1, / \mathrm{m}$. 

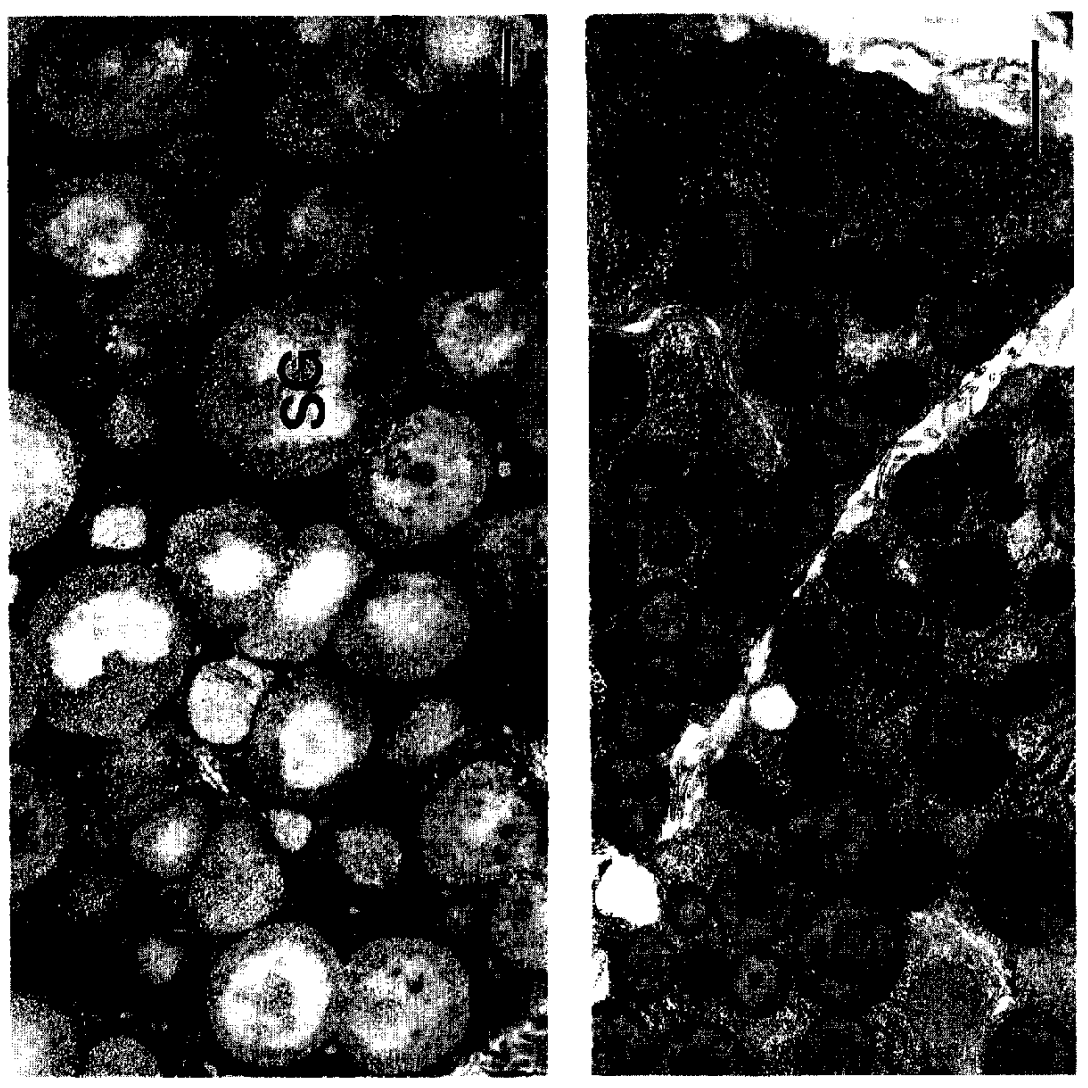

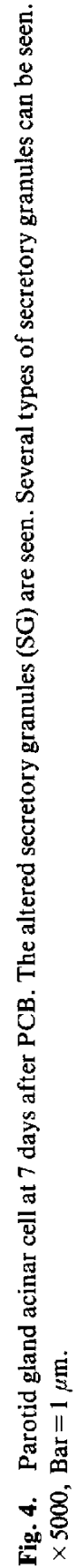

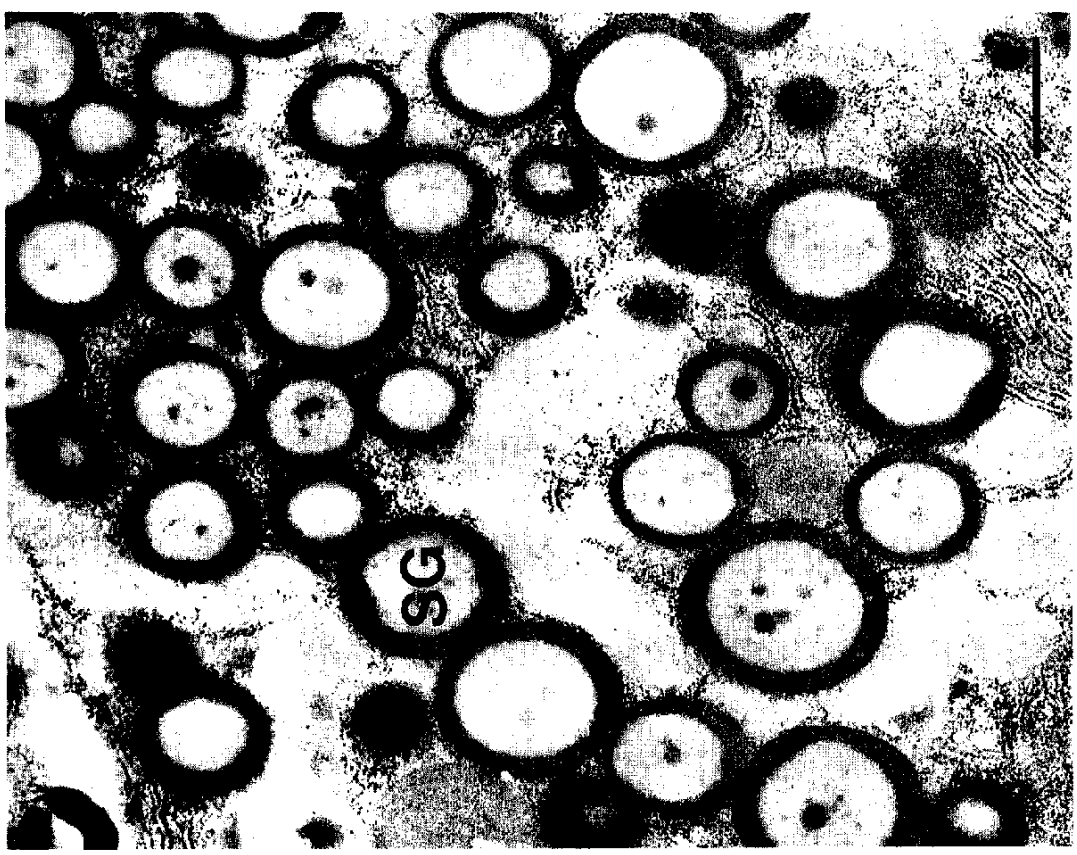




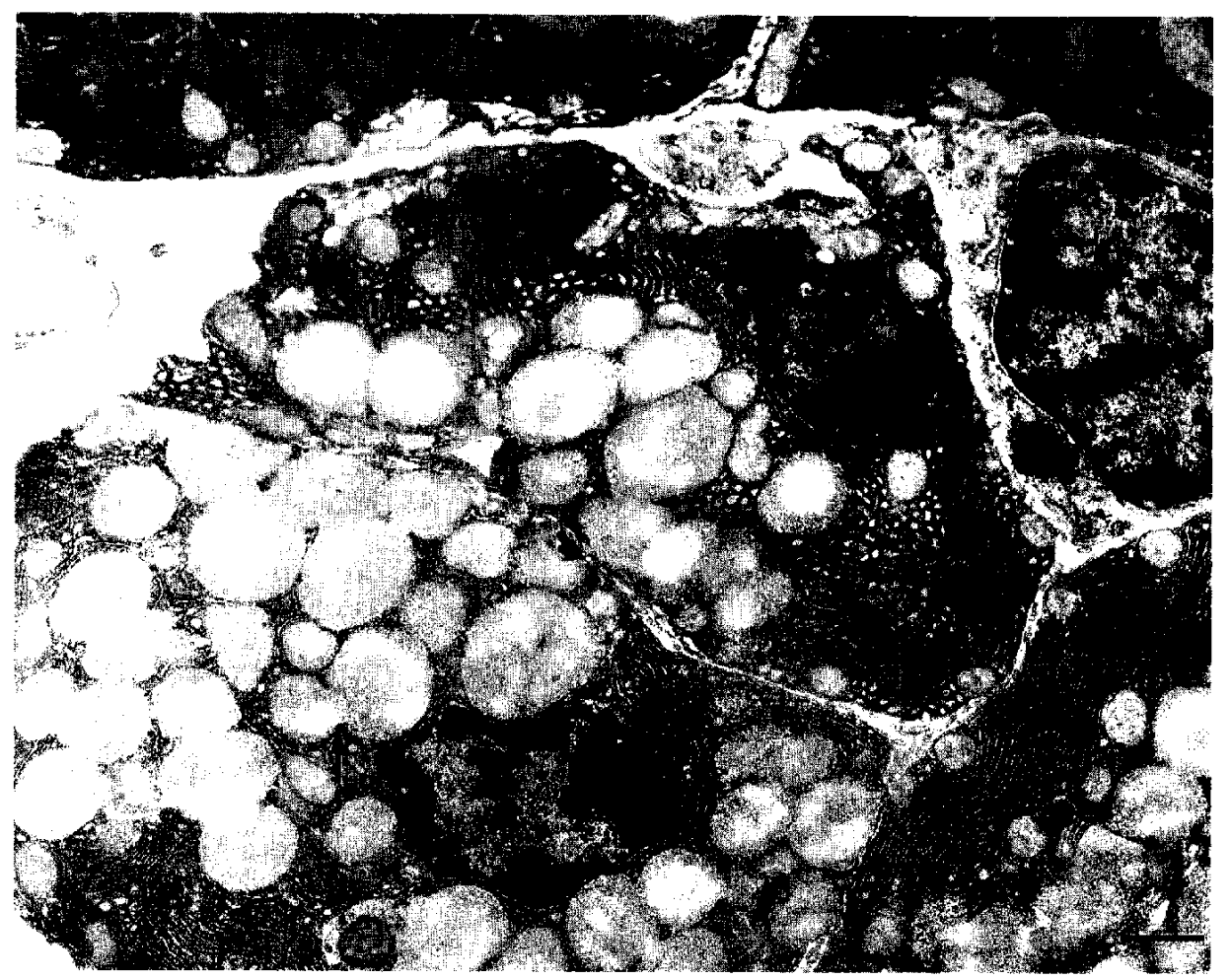

Fig. 5. Parotid gland acinar cells at 7 days after PCB. The secretory granules often fuse (arrows). $\times 5000, \mathrm{Bar}=1 \mu \mathrm{m}$.

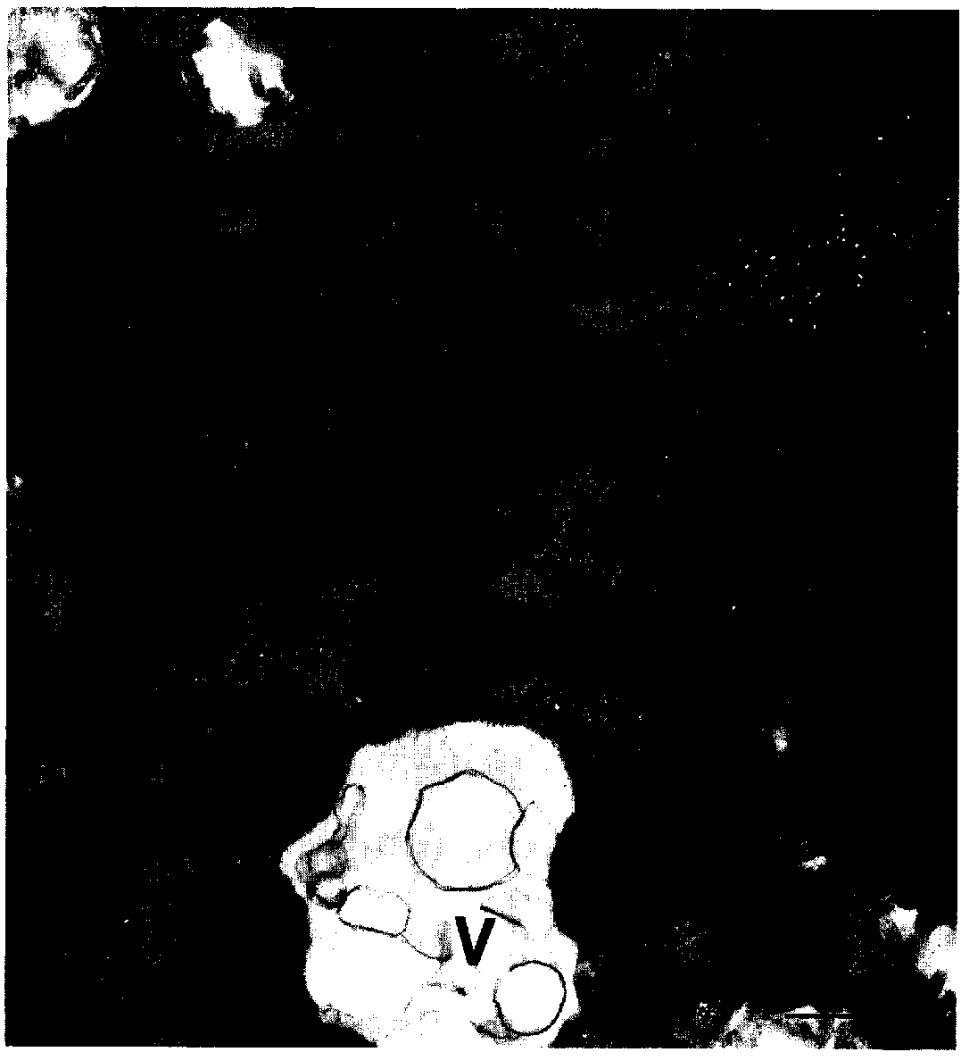

Fig. 6. Parotid acinar cell at 7 days after PCB. Vacuolation (V) is seen. $\times 7000, \mathrm{Bar}=1 \mu \mathrm{m}$. 


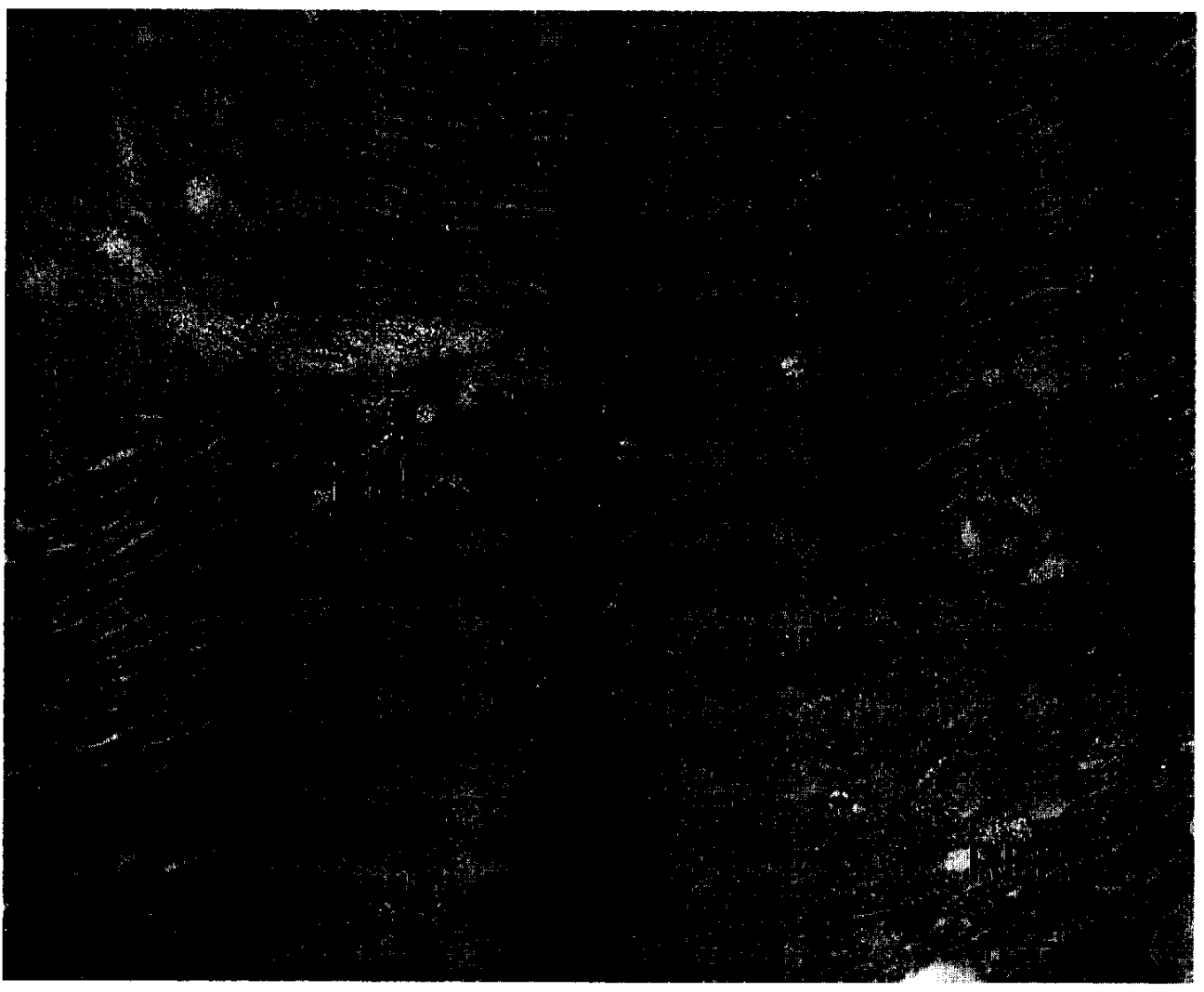

Fig. 7. Parotid acinar cells at 7 days after PCB. The rough endoplasmic reticulum (RER) is irregular and discontinuous. $\times 3500$, Bar $=1 \mu \mathrm{m}$.

Table 1 shows the changes in body weight and parotid gland weight of the mice. The body weight and weight of parotid gland increased at the early stage; however, they had decreased significantly $(P<0.01)$ compared with the controls at 7 days after PCB administration.

The content of vitamin A in parotid glands was remarkably lower than that of the controls at 7 days (Table 2). In addition, NADPH-cytochrome $c$ reductase activities increased significantly at 4 days compared with the controls $(P<0.01)$, while there were no differences at 1 day and 7
Table 1. Changes of body weight and parotid gland weight of mouse after PCB administration

\begin{tabular}{lcc}
\hline $\begin{array}{l}\text { Days after PCB } \\
\text { administration }\end{array}$ & Body weight $(\mathrm{g})$ & $\begin{array}{l}\text { Parotid gland } \\
\text { weight }(\mathrm{g})\end{array}$ \\
\hline Control (0 day) & $24.8 \pm 0.46$ & $0.16 \pm 0.03$ \\
Control (7 days) & $28.2 \pm 0.45$ & $0.23 \pm 0.04$ \\
1 day & $24.4 \pm 0.52$ & $0.11 \pm 0.02$ \\
4 days & $27.8 \pm 0.71$ & $0.14 \pm 0.02$ \\
7 days & $26.1 \pm 0.64^{*}$ & $0.13 \pm 0.02^{*}$ \\
\hline
\end{tabular}

Each value represents the mean \pm S.E. for 7 mice per group. *: $\mathbf{P}<$ 0.01 , vs control ( 7 days).

Table 2. Changes of vitamin A content, NADPH-cytochrome c reductase activities, AMPase activities and alkaline phosphatase activities in mouse parotid gland

\begin{tabular}{lcccc}
\hline $\begin{array}{l}\text { Days after PCB } \\
\text { administration }\end{array}$ & $\begin{array}{c}\text { Vitamin A } \\
(\mu \mathrm{g})^{\mathrm{a}}\end{array}$ & $\begin{array}{l}\text { NADPH-cytochrome c } \\
\text { reductase }(\mathrm{U})^{\mathrm{b}}\end{array}$ & $\begin{array}{c}\text { AMPase } \\
(\mathrm{U})^{\mathrm{b}}\end{array}$ & $\begin{array}{c}\mathrm{AP} \\
(\mathrm{U})^{\mathrm{b}}\end{array}$ \\
\hline Control & $0.025 \pm 0.003$ & $0.84 \pm 0.52$ & $0.042 \pm 0.024$ & $2.89 \pm 1.07$ \\
1 day & $0.026 \pm 0.006$ & $0.62 \pm 0.20$ & $0.102 \pm 0.033^{*}$ & $4.74 \pm 1.23^{*}$ \\
4 days & $0.029 \pm 0.013$ & $1.68 \pm 0.62^{*}$ & $0.046 \pm 0.022$ & $3.46 \pm 0.65$ \\
7 days & $0.006 \pm 0.004^{*}$ & $0.94 \pm 0.27$ & $0.054 \pm 0.020$ & $2.89 \pm 1.26$ \\
\hline
\end{tabular}

After PCB administration to mice, parotid glands were removed and homogenized. Thereafter, vitamin A content, NADPH-cytochrome c reductase, AMPase and alkaline phosphatase activities were measured. Each value represents the mean \pm S.E. for 7 mice per group. ${ }^{*}$ : $\mathrm{P}<0.01$, vs control. ${ }^{\mathrm{a}}$ : $\mu \mathrm{g} / \mathrm{g}$ parotid gland, ${ }^{\mathrm{b}}$ : unit $(\mu \mathrm{mol} / \mathrm{min} / \mathrm{mg}$ protein), AP: alkaline phosphatase. 


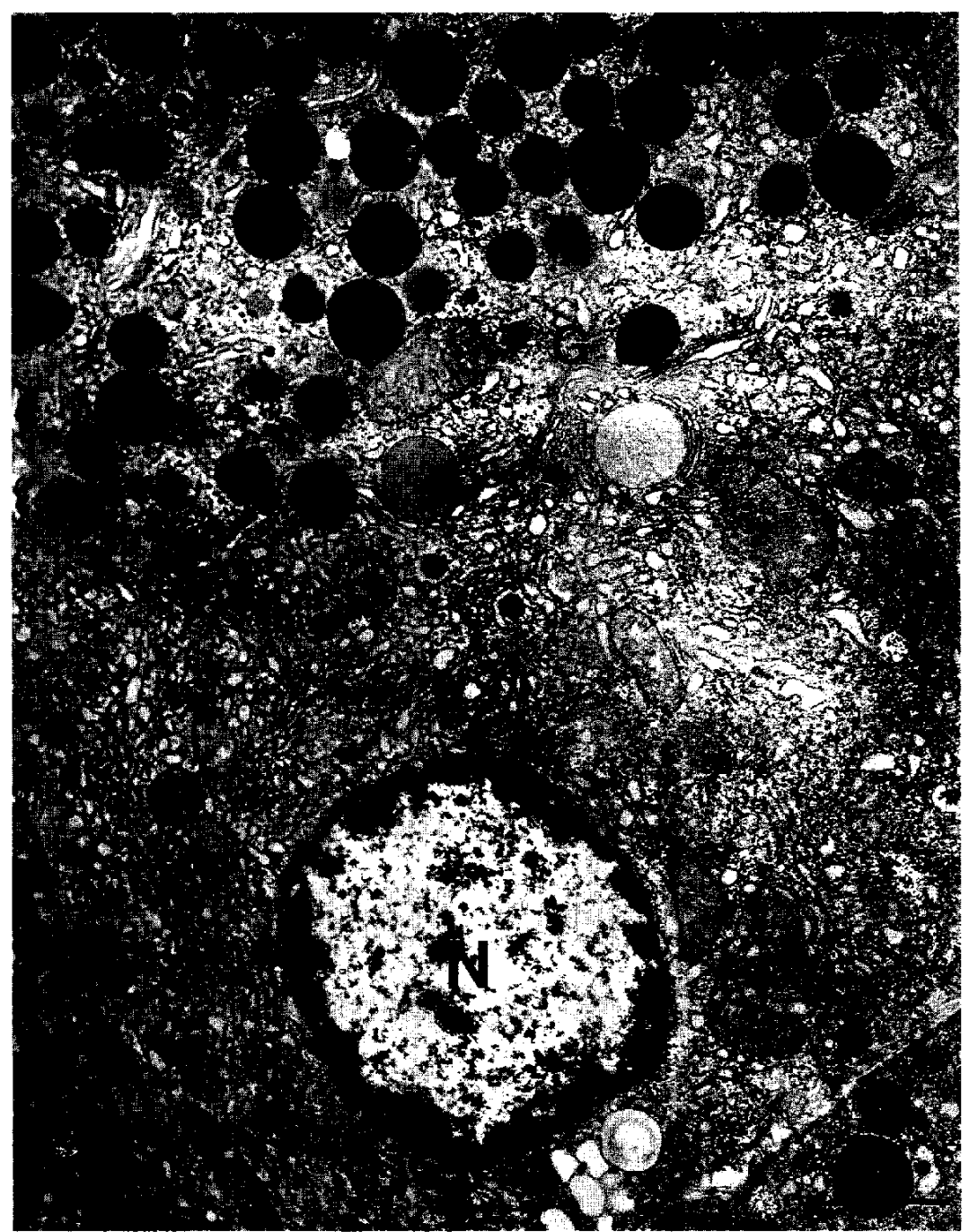

Fig. 8. Parotid acinar cell at 4 weeks after PCB. No morphological changes are found compared with the controls. $\mathrm{N}$, nucleus; SG, secretory granule; G, Golgi. $\times 3500, \mathrm{Bar}=1 \mu \mathrm{m}$.

days after PCB administraion (Table 2). On the other hand, activities of alkaline phosphatase and AMPase increased significantly at 1 day after PCB administration, while their activities showed no difference at 4 days and 7 days after PCB administration (Table 2). At 2, 4, 8 and 16 weeks, vitamin A content and activities of NADPHcytochrome $c$ reductase, alkaline phosphatase, AMPase were not different from those of the controls (data not shown).

\section{DISCUSSION}

In our preliminary experiment to determine the experimental protocol for the present study, ultrastructural changes in parotid glands were examined in mice injected with PCB at doses of either $0.2,2.0$ or $20 \mathrm{mg} / \mathrm{kg}$ body weight by either single injection or successive injections for various durations, from 1 day to 16 weeks. As a result, typical histopathological changes in the mouse parotid gland cells were observed during the first 7 days after a single injection with $2 \mathrm{mg} / \mathrm{kg}$ of PCB. In addition, the extent of histopathological changes in parotid gland cells were essentially same among the four groups, i.e., 2 $\mathrm{mg} / \mathrm{kg}$-treated groups and the $20 \mathrm{mg} / \mathrm{kg}$-treated groups with single or successive injection of PCB, respectively. However, in the $20 \mathrm{mg} / \mathrm{kg}$ group one out of six mice died, perhaps due to general toxicity at this dose. Therefore, a single intraperitoneal injection with $2 \mathrm{mg} / \mathrm{kg}$ of PCB was employed in the present study because of the viability of the animals and reproducibility.

In the present study, we demonstrated that ultrastructural changes occured in mouse parotid gland cells after the PCB injection. In addition to the morphological changes, the vitamin $\mathrm{A}$ content of this tissue decreased. 
In the previous study on the morphological changes in the Ebner's gland after PCB administration, it has been suggested that vitamin A-deficiency caused the histopathological changes of the gland (8). Similarly, it has been also shown that a vitamin A-deficient diet affects the salivery glands (15). In vitamin A-deficient rats, the serous glands were always more severely impaired than the mucous glands, and the characteristic changes were atrophy of acini, distension of ducts, and the formation of cysts and abscesses (16).

In the present study, PCB administration induced marked histopathological changes in secretory glanules, endoplasmic reticulum and the nucleus of the parotid gland acinar cells. Moreover, vitamin A content in the parotid gland decreased in parallel with the histopathological changes. Thus, it is likely that the reduction of vitamin A induced by $\mathrm{PCB}$ caused these morphological changes in the parotid gland cells. In addition, it is generally accepted that the vitamin A deficiency alters the metabolism of mucopolysaccharides in the cells (17). Therefore, remarkable ultrastructural changes were observed in secretory granules, whose major component is mucopolysaccharides, in the present study. These findings clearly demonstrated that vitamin A deficiency occurred in the parotid gland cells.

In the liver, vitamin A content was less than that of the control animals on the 6th day after PCB ingestion (7, 18 ). As to the time course changes of vitamin A content, our result was consistent with those in the previous studies.

Although the mechanism of reduction of vitamin A in animals given PCB is not yet clear, it is presumed that the increase in activities of microsomal drug metabolizing enzymes may be associated with the reduction of vitamin A content. The liver microsomal enzyme system in the hydroxylation of various substances is NADPH- and $\mathrm{O}_{2^{-}}$dependent, and it has a heme protein component like cytochrome P-450. It is well known that these enzymes are induced in animals treated with phenobarbital (19). They also observed a parallel increase in both the content of cytochrome P-450 and the activity of the NADPH-cytochrome $c$ reductase in the liver microsome. Furthermore, the activity of microsomal cytochrome P-450 systems has been shown to increase after PCB administration $(5,6$, $20,21)$. Therefore, the microsomal mixed-function oxidases are considered to be associated with the reduction of hepatic vitamin A caused by PCB administration (22). That is, vitamin A may be metabolized to inactive metabolites by the oxidases, and this results in decreased hepatic vitamin A content.

In the present experiment, we found that $\mathrm{PCB}$ induced NADPH-cytochrome $c$ reductase in the mouse parotid gland. The activity of the enzyme increased 4 days after
PCB administration. We also found that vitamin A content of the parotid gland decreased significantly after induction of NADPH-cytochrome $c$ reductase. Therefore, we speculate that microsomal enzymes such as NADPHcytochrome $c$ reductase is closely associated with the reduction of vitamin $\mathrm{A}$ in mouse parotid glands caused by PCB administration. Moreover, induction of this enzyme in the parotid gland may imply that the decrease of vitamin A could occur not only in the liver, but also locally in the parotid gland.

In fact, NADPH-cytochrome $\mathrm{c}$ reductase was induced in the rat submandibular gland by 3-metylcholanthrene (3-MC) (23). Since PCB is similar to 3-MC in their lipophilicity and the ability of inducing microsomal enzymes $(24,25)$, it is likely that these enzymes also may be induced by PCB in the parotid gland cells. Furthermore, AMPase and alkaline phosphatase were induced prior to NADPH-cytochrome $\mathrm{c}$ reductase. These results indicate that PCB may first affect membrane enzymes, and then other enzymes such as microsomal enzymes are induced.

Although it was evident that our results were mainly due to the secondary effect of systemic vitamin A deficiency after hepatic impairment by PCB, the degree of vitamin $A$ deficiency in parotid glands could be become more serious by the increase in enzymes induced in this tissue in response to $\mathrm{PCB}$.

On the other hand, it cannot be excluded that other factors contribute to development of histopathological changes in the parotid gland, because the induction of drug metabolizing enzymes may also influence the metabolism of lipid soluble substances other than vitamin $A$, and because we did not examine whether the PCB-induced histopathological changes in parotid glands were restored by the supplementation of vitamin $\mathbf{A}$ in the present study.

In conclusion, the histopathological changes in the mouse parotid gland following the $\mathrm{PCB}$ administration may be at least partly due to decreased vitamin $A$ caused by the local induction of NADPH-cytochrome c reductase. Consequently, we speculate that these locally induced enzymes accelerate vitamin A deficiency in the parotid glands, and this is involved in the development of dysfunction in salivary glands such as xerostomia which is frequently observed in Yusho patients.

However, further investigations are necessary to clarify the precise mechanism.

\section{Acknowledgments}

The authors are grateful to Prof. Y. Kato, Dr. H. Sakai (Department of Pharmacology, Nagasaki University School of Dentistry) and Prof. A. Mizuno (First Department of Oral and Maxillofacial Surgery, Nagasaki University School of Dentistry) for their valuable advice and encouragement. 


\section{REFERENCES}

1 Hovinga ME, Sowers $M$ and Humphery HEB: Historical changes in serum PCB and DDT levels in an environmentallyexposed cohort. Arch Environ Contam Toxicol 22, 362-366 (1992)

2 Wolff MS, Fischbein A and Selikoff IJ: Changes in PCB serum concentrations among capacitor manufacturing workers. Environ Res 59, 202-216 (1992)

3 Jongh JD, Wondergem F, Seinen W and Berg MVD: Toxicokinetic interactions between chlorinated aromatic hydrocarbons in the liver of the C57BL/6J mouse: I. Polychlorinated biphenyls (PCBs). Arch Toxicol 67, 453-460 (1993)

4 Villeneuve DC, Grant DL, Philips WEJ, Clark ML and Clecg DJ: Effects of PCB administration on microsomal enzyme activity in pregnant rabbits. Bull Environ Contam Toxicol 6, $120-128$ (1971)

5 Fujita S, Tsuji H, Kato K, Saeki S and Tsukamoto H: Effect of biphenyl chlorides on rat liver microsomes. Fukuoka Acta Med 62, 30-34 (1971) (Abstr in English)

6 Turner JC and Green RS: The effect of a polychlorinated biphenyl (Aroclor 1254) on liver microsomal enzymes in the male rat. Bull Environ Contam Toxicol 12, 669-671 (1974)

7 Innami S, Nakamura A, Miyazaki M, Nagayama S and Nishide E: Further studies on the reduction of vitamin A content in the livers of rats given polychlorinated biphenyls. J Nutr Sci Vitaminol 22, 409-418 (1976)

8 Shimoda T: Electron microscope study of effects of polychrorinated biphenyls on von Ebners gland of the rat. J Kyusyu Dent Soc 42, 253-268 (1988) (Abstr in English)

9 Nielsen SW, Mills JHL, Rousseau JE and Woelfel MS: Parotid duct metaplasia in marginal bovine vitamin A. Am J Vet Res 27, 223-233 (1966)

10 Katsui G: Assay methods of vitamin A. Vitamins 56, 97-101 (1982)

11 Omura $T$ and Takesue S: A new method for simultaneus purification of cytochrome b5 and NADPH-cytochrome c reductase from rat liver microsomes. J Biochem 67, 249-257 (1970)

12 Gabay JE, Heiple JM, Cohn ZA and Nathan CF: Subcellular location and properties of bactericidal factors from human neutrophils. J Exp Med 164, 1407-1421 (1986)

13 Song CS and Bodansky O: Subcellular localization and properties of 5-nucleotidase in the rat liver. J Biol Chem 246,
694-699 (1966)

14 Lowry OH, Rosebrough NJ, Far AL and Randall RJ: Protein mesurement with the Folin phenol reagent. J Biol Chem 193, 265-275 (1951)

15 Hayes KC, McCombs HL and Faherty TP: The fine structure of vitamin A deficiency. Lab Invest 22, $81-89$ (1970)

16 Trowbridge HO: Salivary gland changes in vitamin A deficient rats. Arch Oral Biol 14, 891-900 (1969)

17 Kostulak A: Histochemical studies on the salivary glands in white rats in vitamin A deficiency. Folia Morphol 33, 29-35 (1974)

18 Innami S, Nakamura A, Kato K, Miyazaki M, Nagayama S and Nishide E: Polychlorinated biphenyls toxity and nutrition. Fukuoka Acta Med 66, 579-584 (1975)

19 Das ML, Orrenius S and Ernster L: On the fatty acid and hydrocarbon in rat liver microsomes. Eur $\mathbf{J}$ Biochem 4, 519-523 (1968)

20 Pelissier MA, Siess MH, Lhuissier M, Grolier P, Suschetet M, Narbonne JF, Albrecht $R$ and Robertson LW: Effect of prototypic polychlorinated biphenyls on hepatic and renal vitamin contents and on drug-metabolizing enzymes in rats fed diets containing low or high levels of retinyl palmitate. Food Chem Toxicol 30, 723-729 (1992)

21 Komori M, Kikuchi O, Sakuma T, Funaki J, Kitada $\mathbf{M}$ and Kamataki T: Molecular cloning of monkey liver cytochrome $P$. $450 \mathrm{cDNAs}$ : similarity of the primary sequences to human cytochromes P-450. Biochim Biophys Acta 1171, 141-146 (1992)

22 Saito M, Ikegami S, Ito Y and Innami S: Influence of dietary antioxidants on polychlorinated biphenyls (PCB)-iduced hepatic lipid peroxide formation and vitamin $\mathbf{A}$ reduction in rats. $\mathbf{J}$ Nutr Sci Vitaminol 28, 455-466 (1982)

23 Murakami K: Aryl hydrocarbon hydroxylase in rat submandibular glands. J Hiroshima Dent Soc 18, 37-53 (1986) (Abstr in English)

24 Hanioka N, Saeki KE, Ishida C, Koga N and Yoshimura H: Toxicological assessment of 2,5,2,5,-tetrachlorobiphenyl and its major metabolite, 3-hydroxy-2,5,2,5,-tetrachlorobiphenyl in rats. Fukuoka Acta Med 82, 191-196 (1991) (Abstr in English)

25 Yoshihara S, Nagata $\mathrm{K}$, Wada I, Koga $\mathrm{N}$ and Yoshimura $\mathrm{H}$ : Studies on induction of liver enzymes and toxicity caused by pretreatment with 3-methylcholanthrene-type PCBs. Fukuoka Acta Med 74, $209-216$ (1983) (Abstr in English) 